\title{
The Effect of Storage Time to the Leather Microstructure due to Collagenolytic Bacteria Activity
}

\author{
Novita Kurniawati ${ }^{1}$, Viagian Pastawan ${ }^{1}$, Ragil Yuliatmo ${ }^{2}$, Yuny Erwanto ${ }^{1}$, and \\ Ambar Pertiwiningrum, ${ }^{1, *}$ \\ ${ }^{1}$ Faculty of Animal Science, Universitas Gadjah Mada, Jl. Fauna No. 3 Bulaksumur, Yogyakarta 55281, Indonesia \\ ${ }^{2}$ Department of Leather Processing Technology, Politeknik ATK Yogyakarta, Sewon, Yogyakarta, 55185, Indonesia \\ *Corresponding author. Email: artiwi@mail.ugm.ac.id
}

\begin{abstract}
Raw skin is the common primary material that used in the leather tannery. As an organic material, leather has a risk of microstructure damage from microorganisms. Although the tannery process uses several chemicals and actions to prevent its damage, the long storage time of leather can provide opportunities for microorganisms to regrow. The study aims to know the monitor lizard leather quality through the microstructure condition caused by microorganisms' activity. The various storage time (1, 2, 3 and 4 years) of leather were evaluated by bacterial count. Based on the results, bacterial count and nitrogen content in the leather increased significantly $(\mathrm{P}<0.05)$, while the $\mathrm{pH}$ value and thermal stability decreased significantly after leather storage for two years. So, the longer the storage time, the lower the quality of the leather.
\end{abstract}

Keywords: Storage time, Leather, Microstructure, Collagenase activity.

\section{INTRODUCTION}

As an organic material that has a high protein content, the skin has a risk of damage physically, chemically, and biologically. Biological damage can be caused by microorganisms, which can easily grow in Indonesia due to its tropical climate. Therefore, skin damage caused by microorganisms has the highest probability compared to other types of damage. Microorganisms, such as bacteria and fungi, which are present from raw skin to tanned skin, can hydrolyze proteins and lipids. Proteolysis and lipolysis cause degradation of the raw hide/skin substance.

Skin degradation automatically begins within 5 to 6 hours after animal death. Various species of microorganisms that grow on the skin can cause a decrease in skin quality such as discoloration, destruction of fibers, unpleasant odor, loose skin, and serious damage to the skin surface or tattoo (grain) [1], [2]. Prevention of such damage has been done a lot, including using antimicroorganisms, temperature regulation, $\mathrm{pH}$, and coating in the finishing process. However, skin damage may occur because the activity of microorganisms can be influenced by several factors, including storage time, type of tanning material (including enzymes and tanning agents), and the type of leather preserved. In this study, we investigated the monitor lizard leather quality through the microstructure condition caused by microorganisms' activity. The various storage time $(1,2,3$, and 4 year(s) of leather were evaluated by bacterial count.

\section{MATERIAL AND METHODS}

\subsection{Material}

Freshly flayed monitor lizard skin of average weight $1.5 \mathrm{~kg}$ per skin were purchased from a reptile market. The chrome tanning material was collected from the Laboratory of Leather Finishing, Politeknik ATK Yogyakarta, Indonesia. All materials using in tannery process were an analytical grade. 


\subsection{Methods}

\subsubsection{Sample Preparation}

The preserved samples of known weight were kept in distilled water (ten times by volume of its mass), shaken well by the orbital shaker in a conical flask at $120 \mathrm{rpm}$ for $1 \mathrm{~h}$ to extract the leather. The extract was then filtered through the filter paper.

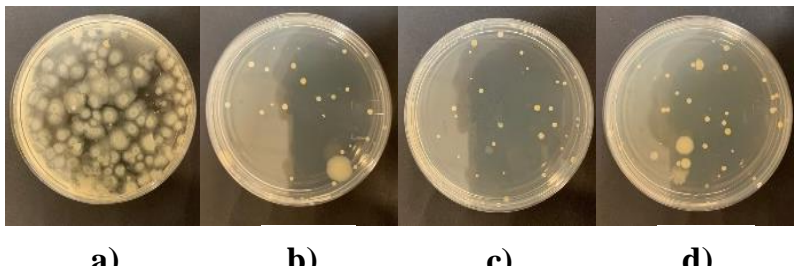

a)

b)

c)

d)

Figure 1 Colony forming bacteria from monitor lizard leather grown in petri dish: a). storage for one year; b). storage for two years; c). storage for three years; and d). storage for four years.

\subsubsection{Determination of Bacterial Count}

A volume of $1 \mathrm{~mL}$ filtrate (from sample preparation) was taken in $9 \mathrm{~mL}$ of sterile water in a vial and shaken well to make uniform suspension of bacteria. Then, 0.1 $\mathrm{mL}$ of the corresponding diluted solution was poured into a sterile Petri plate, and the molten nutrient agar $\left(40{ }^{\circ} \mathrm{C}\right)$ was poured. The Petri plate was shaken gently to get uniform distribution of the bacteria. The Petri plate was incubated at $37{ }^{\circ} \mathrm{C}$ for $48 \mathrm{~h}$. The number of colonies on the agar media was counted using colony counter.

\section{RESULTS AND DISCUSSION}

\subsection{Bacterial Count}

We observed the microorganism contamination using bacterial count of the monitor lizard leather which have been preserved for one, two, three, and four year(s) (Figure 1). The results of total plate count bacteria contaminated the leather between the storage time were significantly different $(\mathrm{P}<0.05)$. Moreover, the preservation of monitor lizard leather for four years showed the least of total bacterial count compared to others (Table 1). On the one- and two-year(s) preservation of the leather, bacterial count in the experimental preserved monitor lizard leather was increased in comparison to the three years preservation. It may be the reason that preservation in the chrome tanned leather has biocidal effects, which inhibit the bacterial population in the long-time preservation [3] The tanning process for the leather products utilizes various organic and inorganic chemicals as well as minerals that functions as tanning agents, preservatives, and increase the leather quality. It manages the skin more durable and provides the added value product, but the tannery material that has been bonded and attached to the skin' collagen is still able to be contaminated by microbial activity, such as collagenolytic bacteria, that can make a damage to the leather [4], [5]. Mannina and Lombardo [6] also stated that leather has a very complicated chemical structure. Many kinds of the chemicals used according to the tanning process, which starts from the beam house, tanning, post-tanning, to the finishing process. They also vary depending on the purpose for which the leather is made, such as for bags, wallets, upper shoes etc. These variations in the use of chemicals can expand the factors that affect the quality of the skin microstructure with different storage periods.

\section{CONCLUSION}

Storage time affected the total plate count in monitor lizard leather. Based on the results, the longer stored time, the lower the bacterial contamination on the leather. Bacterial contamination can affect the skin microstructure. Microstructural damage in different storage times is thought to be due to variations in the chemicals used in the leather manufacturing process.

\section{AUTHORS' CONTRIBUTIONS}

Novita Kurniawati and Viagian Pastawan carried out the experiment. Novita Kurniawati wrote the manuscript with support from Viagian Pastawan and Ragil Yuliatmo. Yuny Erwanto fabricated the data sample. Yuny Erwanto and Ambar Pertiwiningrum helped supervise the project and conceived the original idea. Ambar Pertiwiningrum supervised the project.

\section{ACKNOWLEDGMENTS}

This research was funded by The UGM Strategic Research Program, called Final Project Recognition (RTA).

Table 1. Bacterial count $(\mathrm{CFU} / \mathrm{mL})$ in the preserved monitor lizard leather

\begin{tabular}{|l|l|}
\hline Storage time & Total Plate Count $(x 103)$ \\
\hline One year & $8.9 \pm 2.3^{\mathrm{a}}$ \\
\hline Two years & $4.7 \pm 1.9^{\mathrm{ab}}$ \\
\hline Three years & $3.7 \pm 0.4^{\mathrm{b}}$ \\
\hline Four years & $3.4 \pm 1.1^{\mathrm{b}}$ \\
\hline${ }^{\mathrm{a}, \mathrm{b}}$ Different superscripts in the same column shows a significantly different effect $(\mathrm{P}<0.05)$. \\
\hline
\end{tabular}




\section{REFERENCES}

[1] J. Kanagaraj, R.C. Panda, T. Senthilvelan, S. Gupta, Cleaner approach in leather dyeing using graft copolymer as high performance auxiliary: related kinetics and mechanism, Journal of Cleaner Production, 112, 2016, 4863-4878. DOI: https://doi.org/10.1016/j.jclepro.2015.05.109

[2] B.H. Cadirci, H. Ozgunay, C. Vural, O. Yilmaz, A New Defect on Leather: Microbial Bio-Film, Journal of the American Leather Chemists Association, 105(04), 2010, 369.

[3] J.R. Peixoto, G.C. Silva, R.A. Costa, F.J.R. de Sousa, G.H. Vieira, A.A. Filho, V.R.H. dos Fernandes, In vitro antibacterial effect of aqueous and ethanolic Moringa leaf extracts, Asian Pac. J. Trop. Med., 2011, 201-204. DOI: https://doi.org/10.1016/S1995-7645(11)60069-2

[4] J. Skóra, B. Gutarowska, L. Stepien, A. Otlewska, K. Pielech-Przybylska, The Evaluation of Microbial Contamination in the Working Environment of Tanneries, Medycyna Pracy 65 (February), 2014, 15-32.

DOI:

DOI: https://doi.org/10.13075/mp.5893.2014.005

[5] Z. Zhang, Yu, Y.R. Li, Y.L. Chun, L.C. Xiu, Diversity, Structures, and Collagen-Degrading Mechanisms of Bacterial Collagenolytic Proteases, Edited by F. E. Löffler. Applied and Environmental Microbiology 81(18), 2015, 6098-6107. DOI: https://doi.org/10.1128/AEM.00883-15

[6] L. Mannina, A. Lombardo, Diagnostic analyses for the study of materials, technique and state of preservation of a gilt and painted leather of the XVIII Century, Procedia Chemistry 8, 2013, 202 211.

DOI: https://doi.org/10.1016/j.proche.2013.03.026 